\begin{abstract}
Developing and transition countries have increasingly engaged in the signing of bilateral investment treaties (BITs) in order to attract FDI, based on the widely shared view that FDI can contribute significantly to economic development and poverty reduction. However, the degree to which foreign investments can be expected to generate employment, offer access to international technology and know-how, and ultimately create growth, varies considerably depending on the type of investment. It is therefore important to determine what type of FDI is attracted by BITs. By providing a legal commitment to the fair and equitable treatment of foreign investors, BITs aim to decrease investment risk and to attract foreign investors. We argue that BITs can be expected to be most effective in those sectors of the economy with a larger risk of expropriation, i.e. sectors characterized by large sunk costs, relatively low levels of firm-specific know-how and in sectors that are politically sensitive to foreign ownership.

This paper represents the first attempt to empirically study the heterogeneous effect that BITs may have across different sectors of investments. We analyze investments made in 13 countries in the former Soviet Union and Central and Eastern Europe, disaggregated over 7 sectors. We indeed find the effect of BITs to differ considerably across sectors of investment. Using capital intensity as a proxy, we confirm that FDI in those sectors with higher sunk costs responds more strongly to the signing of BITs. Given the considerable differences in the development impact that can be expected from FDI in different sectors, it remains to be shown whether BITs are an effective tool to attract those types of investments that are most beneficial for the development of the host economy.
\end{abstract}




\section{BILATERAL INVESTMENT TREATIES AND FDI: DOES THE SECTOR MATTER?}

\section{INTRODUCTION}

After a period of reluctance towards foreign direct investment (FDI), developing countries have started opening up to international capital flows since the 1980s (UNCTAD, 1998). This policy

change was animated by the view that foreign investments foster development by creating employment and transferring new technologies and know-how ${ }^{1}$. During the 1990s also transition countries in Eastern Europe and the former Soviet Union started removing barriers to foreign entry in their markets, while implementing favorable trade and tax policies and undertaking various investment promotion activities to improve the attractiveness of their countries (UNCTAD, 1998, Nunnenkamp, 2004) ${ }^{2}$. Still, foreign investors often face significant uncertainty regarding the stability of these favorable conditions over time and have to consider that governments may have incentives to reverse course, for example by increasing taxes or by expropriating once investments have occurred (Henisz, 2002).

Over the past two decades, Bilateral Investment Treaties (BITs) have become the predominant international legal mechanism for the encouragement and governance of FDI (Elkins et al., 2006). By providing a legal commitment to the fair and equitable treatment of foreign investors, BITs aim to decrease the (perception of) investment risk and to attract foreign investors. Between 1990 and 2009, the number of BITs signed by developing countries increased from 200 to about 2000 (UNCTAD, 2012b). Not surprisingly, this marked evolution raised questions on the effectiveness of BITs in attracting FDI. Hallward-Driemeier (2003) studies bilateral FDI flows for a small sample of host countries and finds little support for the effectiveness of BITs. Considering aggregate FDI flows for a larger sample of host countries, Neumayer and Spess (2005) find instead a positive effect of BITs, which is stronger for countries with weaker institutions. More recent 
BILATERAL INVESTMENT TREATIES AND FDI: DOES THE SECTOR MATTER?

empirical studies typically consider bilateral FDI flows and implement more advanced methodologies to address the endogeneity of BITs, and confirm that BITs stimulate foreign investments (e.g. Egger and Merlo, 2007; Busse et al., 2010; Berger et al., 2013). Egger and Merlo (2012) analyse the effect of BITs at the micro-level and also find a positive effect of BITs on multinational firm activity.

One of the main shortcomings of existing studies is that they all assess the impact of BITs on total FDI flows, without distinguishing by type of investment. In this paper, we argue that the key mechanism through which BITs are thought to affect FDI (i.e. increased investment protection), suggests that their effectiveness depends on the specific type of investment. Projects involving larger sunk investments (i.e. having a higher degree of irreversibility) stand to lose more in case of expropriation, and are less likely to be undertaken in an uncertain environment. Similarly, investment projects that are considered politically sensitive are more susceptible to policy reversals and expropriations. The extra protection provided by a BIT is therefore likely to disproportionally benefit these types of foreign investments, while it may hardly affect others.

The fact that BITs may attract certain types of FDI more than others is especially relevant given that the impact of FDI on economic growth and poverty reduction depends on the interplay of host-country conditions and industry characteristics (Nunnenkamp, 2004). Foreign investments contribute more to poverty alleviation when they are targeted at sectors and industries that are more labor-intensive and have frequent interactions with local firms, such that they can create spillovers of technology, managerial knowledge and trade networks (OECD, 2002; Mayer-Foulkes and Nunnenkamp, 2009). Yet, not all types of FDI contribute equally to knowledge spillovers through linkages with the domestic economy and to employment generation, tax revenues and 
export growth (Crespo and Fontoura, 2007; Iršová and Havránek, 2013; Amendolagine et al., 2013; UNCTAD, 2001).

Alfaro and Charlton (2007) and Aykut and Sayek (2007) show that the positive impact of FDI is conditional on the sector of investment. Foreign investment in the primary sector has generally few linkages to the local economy and contributes little to employment generation (Asiedu, 2004) and economic growth (Nunnenkamp, 2004; Aykut and Sayek, 2007; Chakraborty and Nunnenkamp, 2008; UNCTAD, 2001). Investments in the manufacturing sector are generally believed to be the most relevant for the diffusion of advanced technology $(\mathrm{Xu}, 2000)$ and are often found to have the largest growth effects (Alfaro and Charlton, 2007; Aykut and Sayek, 2007; Chakraborty and Nunnenkamp, 2008). But even within manufacturing there may be important differences, as the extent of linkages with domestic suppliers may differ considerably across specific industries (Javorcik, 2004). For the services sector, UNCTAD (2001) argues that there is less potential for linkages and spillovers -and thus for growth- than in the manufacturing sector, although in the retail and hotel sector there may be considerable potential for local linkages. Empirical results in this case are ambiguous. While Aykut and Sayek (2007) find that a higher share of services in total FDI has a negative effect on growth, Nunnenkamp and Spatz (2004) and Iršová and Havránek (2013) find the largest growth effects in the service sector.

If developing countries engage in BITs in order to attract foreign investments that could contribute to economic growth and poverty alleviation, it appears crucial to understand which type of FDI is actually attracted by these agreements. With this paper we therefore go beyond the standard question whether BITs attract FDI and we study, for the first time, the heterogeneous effects of BITs across sectors of the economy. In this way we will be able to better understand 
whether BITs are successful in attracting those foreign investments from which the largest contribution to the host countries can be expected.

This paper also contributes more generally to the (vast) literature on the determinants of FDI flows (for an overview see Blonigen, 2005 and Chakrabarti, 2001). Clearly, the presence of an international legal agreements is just one of the many elements affecting investment decisions. Other important dimensions, such as market size, economic development, trade openness, labor costs, and institutional quality play a major role. In this paper we therefore control for these traditional determinants of FDI.

In our empirical analysis, we use sectorally disaggregated data on FDI stocks for 13 countries in the Former Soviet Union and Central and Eastern Europe. Our estimates for the overall effect of BITs are in line with the recent literature: their impact on the FDI stock is positive and non-negligible, with one additional BIT increasing the stock of FDI by about 1 to 2 percent. But more importantly, our results show that there are large differences in the effectiveness of BITs across sectors: BITs appear particularly successful in attracting foreign investments in utilities and real estate, while no effect is found for investments in manufacturing and services. Given that the largest gains in terms of development for the host economies are expected from these latter sectors, our results cast doubts on whether the success of the BITs signed so far have delivered the expected benefits to the host countries.

In the next section we develop a conceptual framework that explains why we expect the impact of BITs to differ across different sectors of FDI. Section 3 describes the data used in our empirical analysis, while section 4 discusses the empirical estimation strategy. Section 5 reports the results and section 6 concludes. 


\section{CONCEPTUAL FRAMEWORK}

(a) BITs and FDI

BITs specify a number of guarantees for investors from the signatory countries, including the right to freely transfer funds and assets, minimum treatment standards and protection from expropriation $^{3}$. A crucial component of these treaties is the right to international arbitration typically through the International Centre for Settlement of Investment Disputes (ICSID) $)^{4}$ - in case of an investment dispute (Elkins et al., 2006; Büthe and Milner, 2008). Especially in developing or transition countries, where political instability and frequent leadership turnover have been found to be highly correlated with the likelihood of expropriation acts (Li, 2009), the guarantees provided by a BIT may considerably decrease the risk of investment. This risk typically results from a credible commitment problem (Simmons, 2000; Henisz, 2002), or "obsolescence bargain" (Vernon, 1971): a government can assure investors that it will not expropriate investments, yet, once the costs of investments are borne by the investors, a myopic host country government might find it optimal to breach its promises and decide to extract rents or expropriate property or funds. Anticipating this behavior, investors will not trust the promises made by the government in the first place and will refrain from investing in the country, which will ultimately lead to underinvestment. By providing a credible commitment device, BITs help to overcome this problem and to attract FDI (Vandevelde, 1998; Elkins et al., 2006).

(b) Heterogeneous effects across sector

While investments in developing or transition economies typically face higher risks than similar investments in developed countries, these risks are likely to vary according to the characteristics of the investment project. Three key determinants of the risk of expropriation have been identified 
in the literature (Hajzler, 2012). First, the risk of expropriation increases with the level of sunk costs of the investment, since it is relatively easier and more profitable for a government to take over an investment that cannot easily be reversed. This is typically the case for investments in resource extracting industries and utilities provision. For example, mineral extraction requires large investments in exploration and excavation infrastructure before revenues are realized. Similarly, the utilities sector is characterized by high fixed startup costs and relatively low variable costs. This makes it particularly tempting for a government to reap the returns through expropriation, once these sunk investments are made.

Second, the more important non-transferrable assets are, the lower the risk of expropriation. Governments can indeed expropriate capital, but they cannot get hold of more immaterial and firmspecific factors of production, such as managerial expertise, which appears especially important in many manufacturing and service industries (Eaton and Gersovitz, 1984; Raff, 1992). The returns from investments in sectors with an important degree of firm-specific knowledge may therefore be considerably lower for the government than for the foreign company and, as a consequence, the government has less incentives to expropriate.

Third, the risk of expropriation or policy reversal is higher in sectors that are politically sensitive or "strategic" to the host country. Extractive industries, utilities, railways, communications and national defense are often considered to be crucial for political and economic independence and national security (Kobrin, 1980; Shafer, 2009). Utilities are typically considered as basic provisions that should be in public ownership, while natural resources are considered to be owned by the host country and their exploitation by foreign nationals may easily encounter protests (Kobrin, 1984; Jodice, 1980). Moreover, the high variability in mineral prices may result 
in governments wanting to renegotiate contracts that are suddenly perceived as more generous to the investor than expected (Duncan, 2006; Engel and Fischer, 2010).

The available empirical evidence confirms that the risk of expropriation varies across sectors of investment, with the most frequent targets being investments in natural resource extraction, utilities, mass communications, and (in the 1960s and 70s) banking (Truitt, 1970; Kobrin, 1980). Table 1, which is taken from Hajzler (2012), shows the share of each sector in the number of direct expropriation acts by developing countries between 1960 and $2006 .^{5}$

\section{[Table 1 about here]}

Direct expropriations are most prevalent in the primary sector. Utilities also account for a considerable share, especially considering that their share in total FDI stock in developing countries is only about $2 \%$ (UNCTAD, 2012c). Given that the manufacturing sector makes up more than half of the total stock of foreign investment in developing countries, the share of the manufacturing sector in the total number of direct expropriations (13.6 to 27.4 percent, depending on the time period) is relatively low. Inasmuch as the risk of expropriation varies with the sector of investment, as suggested by Table 1, it is reasonable to expect that the effects of a reduction in the risk of expropriation generated by the signing of a BIT will vary as well across sector.

Before moving to the empirical analysis, a first indication that this might indeed be the case comes from the records of investor-state dispute settlement cases at the international investment arbitration courts (mostly ICSID) between 1987 and 2010 (UNCTAD, 2012b). Figure 1 compares the share of each sector in the global FDI stock to its share in the total number of investor state disputes laid down since 1987.

[Figure 1 about here] 
The pattern derived from the disputes appears largely similar to the one observed based on the number of expropriation acts in Table 1. The utilities sector accounts for $23.6 \%$ of total disputes, while accounting for about $2 \%$ of the global stock of foreign investments in 1990 and 2010. Also the share in total investor-state disputes of mining, agriculture, and real estate is high compared to their share in global FDI stock (Figure 1). The number of disputes concerning investments in the manufacturing sector is non-negligible (18\% of disputes), but is low when considering that manufacturing made up $43 \%$ of the FDI stock in 1990 and $21 \%$ in 2010 - and even more than $50 \%$ when considering only developing countries. Moreover, note that within manufacturing, $35 \%$ of arbitration cases relate to investments in chemicals, oil refineries and steel production, which are the industries with the highest measure of sunk costs within the manufacturing sector, as we will show later on in our analysis. Also the number of disputes regarding investments in services or banking ${ }^{6}$ is low, relative to the corresponding shares in FDI stock.

Based on the arguments outlined above and on the suggestive evidence coming from the investor-state disputes data, we hypothesize that FDI is more responsive to the signature or ratification of a BIT in certain sectors than in others. Moreover, we argue that this can at least partially be explained by the importance of sunk costs, which result in a higher degree of irreversibility of investments in these sectors. Before outlining our empirical strategy to test these hypotheses, the next section describes the data that are used and the definition of the key variables. 


\section{DATA DESCRIPTION}

(a) Data

Our sample consists of FDI data for 7 different sectors in 13 countries in Central and Eastern Europe and the Former Soviet Union over the period 1994-2009, collected by the Vienna Institute for International Economic Studies (WIIW, 2010). While the limited size of the dataset obviously imposes constraints on our empirical analysis as well as on the geographical representativeness of our results, as far as we known it is the only available dataset recording sectorally disaggregated FDI. ${ }^{7}$ Moreover, the specific set of countries in the sample seems to be especially relevant for a study on BITs: not only have these countries increasingly engaged in signing investment treaties since the early 1990s - with 800 new BITs entering into force between 1990 and 2009, but also previous studies suggest that BITs may be particularly effective for the Central and Eastern European economies (Busse et al. 2010; UNCTAD, 2009) ${ }^{8}$.

Table A1 gives an overview of the countries and years covered in the WIIW dataset. The data cover seven economic sectors: agriculture, mining, manufacturing, banking, real estate, utilities, and other services. Given that FDI data are missing for the agricultural sector in Slovenia and the Slovak Republic, this results in 88 country-sector cross-sectional units, with an average of 11 years of observations per cross-sectional unit. Figure A1 illustrates the evolution of FDI stock per sector over time for each country separately.

Table 2 indicates the mean, minimum and maximum volume of FDI stock in each sector and shows the share of each sector in the total FDI stock. With on average 35.4 percent of the total FDI stock, manufacturing is the most important sector for the countries in our sample, followed by services with 28.4 percent and banking with 19.8 percent. Note that the share of FDI in agriculture, mining and utilities is low for all countries. 
BILATERAL INVESTMENT TREATIES AND FDI: DOES THE SECTOR MATTER?

\section{[Table 2 about here]}

For the manufacturing sector only, the WIIW dataset contains disaggregated data by industry. For the other sectors no data at the industry level is available. In addition to considering the manufacturing sector as a whole, we therefore perform a robustness test on these disaggregated, industry-level data, to test whether also within the manufacturing sector, those industries with higher sunk costs respond more strongly to the signature of BITs. Data is available on FDI stocks for 12 different manufacturing industries in 12 countries (industry-disaggregated data is missing for Bulgaria). The list of manufacturing industries considered is presented in Table A2 in Appendix. Due to some missing observations for specific industries in some countries, the sample consists of 122 cross-sectional units with an average of 9 time observations per country-industry combination.

The dependent variable of our main analysis is the total stock of FDI in the host country in a certain sector. Our measure is therefore not disaggregated by home country of investment. The literature has sometimes relied on dyadic FDI data (home-host country pairs) (e.g. Egger and Merlo, 2007; Busse et al., 2010), but the lack of FDI data that are disaggregated at the same time by home country and by sector does not allow us to do the same. There are in any case also valid arguments for not differentiating FDI by country of origin. When country A and B sign a BIT, country A commits to the protection and fair treatment of investors from country B only. However, in addition to a direct "commitment effect" on investment from signatory country B, there could also be a "signaling effect" that stimulates investments from countries not directly covered by the agreement (Neumayer and Spess, 2005; Tobin and Rose-Ackerman, 2011). Even though not protected by the BIT themselves, foreign investors from a third country may indeed consider a BIT as an easily observable and credible signal that the host country is serious about attracting and 
BILATERAL INVESTMENT TREATIES AND FDI: DOES THE SECTOR MATTER?

protecting FDI. Kerner (2009) finds that the more BITs a country engages in, the stronger this signal is. A BIT might thus not only encourage investment from the signatory partner, but there may also be a positive indirect effect on investments from other countries. A dyadic approach may therefore underestimate the effect of BITs on FDI, because it ignores this indirect "signaling effect".

Information on BITs is taken from UNCTAD's IIA database (UNCTAD, 2012b), which records information on both the date of signature and of ratification of each BIT. Note that a BIT is signed between two countries and covers foreign investments in all sectors. For each host country, we construct the total number of BITs that are ratified in a particular year as the explanatory variable of interest. We use the number of ratified BITs rather than the number of BITs that are signed, because between the moment of signature and ratification several years may pass, and it is only upon ratification that the BIT enters into force and that actual commitments are made. As a robustness check, we will replicate the regressions using the number of signed BITs and show that our main conclusions hold.

Figure A1 in appendix shows the number of BITs signed by each of the host countries in our sample over the period 1994-2009. By 2009, each country had signed BITs with on average 48 other countries, of which at least 15 were EU member states, and all except Hungary had ratified a BIT with the United States. With respectively 72 and 62 BITs, Romania and Czech Republic are the countries with the largest number of BITs in force by 2009, while Estonia and Macedonia engaged in only 23 and 28 BITs, respectively.

In our empirical analysis we will include also a number of control variables that are collected from different sources. Data on the monthly wage in manufacturing are taken from ILO (ILO, 2012). Political institutional quality is measured through the Political Constraint Index 
(Henisz, 2006), which is a composite index of variables measuring the political structures of a country and their ability to support credible commitments. It ranges from 0 to 1 , with a higher value indicating better institutions ${ }^{9}$. The inflation rate and the measure of trade openness (sum of exports and imports relative to GDP) are taken from the World Development Indicators (World Bank, 2012).

(b) Measuring sunkness across sectors

Sunk costs are difficult to measure and we will rely on two proxies that have been proposed in the literature. Following Lambson and Jensen (1998) and Gschwandtner and Lambson (2002), the first proxy is the average fixed capital stock per firm in the sector, calculated as the total real fixed capital stock divided by the average number of firms in that sector. High fixed capital requirements make investments less easily reversible and are likely to lead to markets with relatively fewer and larger firms (Ghosal and Loungani, 2000).

The second proxy is the capital-labor ratio, calculated as the average total real fixed capital stock in the sector divided by the average number of workers in the sector. This proxy captures the fact that sunk costs are likely higher in more capital-intensive sectors and industries than in laborintensive sectors and industries. This measure was proposed by Cabral (1995) and is used for example in Pennings and Sleuwagen (2000) and Gschwandtner and Lambson (2002).

These are certainly not perfect measures. For instance, neither of them takes into account the depreciation and the scrap value of capital, which could lead to an overestimation of the sunk costs. At the same time, some intangible and recurring sunk costs, such as market research, legal fees, advertising costs etc. are excluded from our measure of capital. Nevertheless, we believe that 
- in the absence of detailed firm-level data on sunk costs - these are the best approximations we can rely on. We will show that both proxies yield qualitatively very similar results.

The two proxy variables for sunkness are constructed based on the capital and labor accounts in the EUKLEMS (2011) database. Since complete data is only available for a limited number of countries and years, we constructed them relying on information for Germany, which is the largest capital exporter to the countries considered in our analysis ${ }^{10}$. Based on the available data, the capital-labor ratio is averaged over the period 1997-2007, while the capital-per-firm proxy is averaged over the period 1991-1997.

The value of these proxies for each of the seven sectors that will be considered in our empirical analysis are presented in Figures $2 \mathrm{a}$ and $2 \mathrm{~b}$. They confirm the intuition that utilities and real estate - and to a lesser extent also mining - are the sectors with the highest degree of sunk costs. In light of our previous analysis, this would suggest that investors in these sectors are more susceptible to uncertain investment environments and are thus likely to respond more strongly to a BIT. The services sector has the lowest value for both proxies and investment in this sector is therefore predicted to be less sensitive to the introduction of a BIT. Both proxies are also constructed for each of the manufacturing industries (Figure A 2a and A 2b in Appendix). Coke and refined petroleum, chemicals and transport are the manufacturing sectors with the highest value of sunk costs.

[Figure $2 a$ and $b$ about here]

\section{EMPIRICAL SPECIFICATION}

In order to estimate the effect of BITs on FDI stocks we rely on fixed effects models. Given that it takes some time for FDI to adjust, and in order to reduce simultaneity problems, the explanatory variables are lagged by one year. We also include the lagged dependent variable on the right-hand 
side to account for the sluggish adjustment of FDI stocks. We will consider three different models to uncover the effect of BITs on FDI. The results will be reported in three separate tables in the next section.

$$
\begin{gathered}
F D I_{i s t}=\alpha F D I_{i s(t-1)}+\beta B I T_{i(t-1)}+\gamma^{\prime} x_{i(t-1)}+\tau_{t}+\mu_{i s}+\varepsilon_{i s t} \\
F D I_{i s t}=\alpha F D I_{i s(t-1)}+\beta_{s} B I T_{i(t-1)}+\gamma^{\prime} x_{i(t-1)}+\tau_{t}+\mu_{i s}+\varepsilon_{i s t} \\
F D I_{i s t}=\alpha F D I_{i s(t-1)}+\beta^{\prime} S_{s} B I T_{i(t-1)}+\gamma^{\prime} x_{i(t-1)}+\tau_{t}+\mu_{i s}+\varepsilon_{i s t} \\
\text { with } i=1, \ldots, 13 ; s=1, \ldots, 6 ; t=2, \ldots, T .
\end{gathered}
$$

Here, the subscript $i$ indicates the host country, $s$ indicates the sector and $t$ indicates the year. The variable $F D I_{i s t}\left(F D I_{i t}\right)$ is the logarithm of FDI stock in country $i$, sector $s$ and year $t$. The explanatory variable of interest $B I T_{i t}$ is the total number of BITs ratified by host country $i$ in year $t$. The error term is composed of an idiosyncratic component $\varepsilon_{i s t}$, a country-sector specific fixed effect $\mu_{i s} \mu_{i}$, and year dummies $\tau_{t}$, which are $t_{t}$ included to capture eventual common shocks in FDI across host countries ${ }^{11}$.

In the first model (A) we analyze the effect of an additional BIT being ratified without allowing the effect to differ across sectors. This corresponds to the functional form that has been analyzed in earlier studies. In the second model (B) the effect of BITs is instead allowed to differ across sectors, in order to determine whether BITs attract more FDI in certain sectors rather than in others. This means that we estimate a separate BIT coefficient $\beta_{s}$ for each sector $s$, rather than estimating a common coefficient $\beta$ for all sectors. Finally, in model (C) we interact the BIT variable with the sunkness $\left(S_{S}\right)$ of each sector, using the de-meaned average fixed capital stock per firm as a proxy. In this way we allow the effect of a BIT to change linearly as a function of the irreversibility of investments in the sector. This specification amounts to assuming $\beta_{s}=\beta_{1}+$ 
$\beta_{2} S_{s}$ where the parameter $\beta_{1}$ captures the effect of signing an additional BIT common to all sectors, while $\beta_{2}$ captures the additional effect for sector $s$ due to its specific level of sunkness $S_{s}$.

We will show that our results are robust to using various different specifications. As a first robustness test, we replace the fixed capital stock per firm with the capital-labor ratio as proxy for sunkness $S_{s}$ (results can be found in Table A3 in appendix). Secondly, rather than considering the number of BITs ratified, we estimate the effect of the number of BITs signed, although we expect the simple signature to have a smaller impact on FDI flows. In addition, we repeat the estimation only considering the number of BITs ratified with the top 15 capital exporters. In this case we expect the effect of BITs to be larger, because the signatory partner is a country with a large stock of outward FDI. Finally, we will test whether our results regarding the role of sunk costs on the effectiveness of BITs (model C) holds not only when considering different sectors, but also when considering different industries within the manufacturing sector.

Each regression includes a standard set of explanatory variables of FDI $\left(x_{i t}\right)$. This includes the logarithm of the real monthly wage, which can be considered a proxy for labor cost - in which case the expected coefficient would be negative - but it can also capture purchasing power or the productivity of the labor force - in which case we would expect a positive coefficient. Which of these effects is most important for FDI is an empirical question. Given the very high correlation between wage levels and GDP per capita, we leave the latter out of our analysis, to avoid multicollinearity. An increase in the real wage over time can thus also be interpreted as an indicator of economic growth and growing market size. We also include inflation, which is often used as an indicator of macroeconomic stability. Also in this case the expected sign of the coefficient is ambiguous. High levels of inflation are found to be bad for economic growth (and FDI), but compared to a very low or negative level of inflation, some inflation is expected to be beneficial 
for growth (Kahn and Senhadji, 2001). To account for this non-linearity to some extent, we include the logarithmic transformation of the inflation variable. Finally, we include a measure of trade openness and the Political Constraints Index. In both cases we expect a positive coefficient, as both higher openness and higher quality of political institutions are expected to stimulate FDI inflows.

While the dynamic fixed effects model takes into account the fact that FDI stocks adjust slowly, it brings along another problem. The inclusion of the lagged values of the dependent variable in a fixed effects estimation causes the so-called 'Nickell bias' (Nickell, 1981). To address this problem we resort to the GMM (Generalized Method of Moments) estimator proposed by Arellano and Bond (1991). In particular, we use the forward orthogonal deviations transformation (Arellano and Bover, 1995) to remove the fixed effects, after which the transformed 'differences to the future mean' of the lagged dependent variable are instrumented with past levels of the dependent variable ${ }^{12}$. In our basic specification we will use lags 2 to 4 . In order to limit the number of instruments, we collapse the instrument matrix (Roodman, 2009a). We always report the test statistics for the joint validity of instruments, i.e. the Sargan and Hansen tests of over-identifying restrictions. As this GMM estimator may suffer from bias in small samples, we also report standard OLS results with a lagged dependent variable and fixed effects, ignoring the Nickell bias.

Finally, we attempt to address concerns about the potential endogeneity bias in the BIT coefficient. The direction of such bias is not a priori clear. The signature of BITs may be (partially) determined by investors lobbying for protection of existing or planned investment projects. Such reverse causality would lead to an overestimation of the real effect. On the other hand, if BITs are more likely to be signed by those countries in which foreign investments flow in at a slower rate, for instance because of a lack of credibility, poor infrastructure or poorly developed markets (as 
suggested by Neumayer, 2006), and if this slower build-up of FDI is not fully captured by the control variables, we would underestimate the real effect. Note that even if we would not succeed in entirely removing endogeneity and in estimating the precise causal effect, this does not undermine our main argument. If investors in high sunk cost sectors are more likely to lobby, this would suggest that our estimated effect partly captures the fact that a BIT is more likely to arise when high sunk investments are already planned anyway. Hence, even if our estimates reflect correlation rather than causality, results would still suggest that this correlation is higher for sectors with a high degree of irreversibility than for other sectors, which is our main point.

We will in any case make use of two different strategies to attempt to solve these potential endogeneity problems and obtain estimates of the causal impact of BITs. First, we add a countrytime trend to the dynamic fixed effects specification, in addition to the country-sector fixed effects, to control for potential different growth paths of FDI stocks across countries. In as far as reverse causality makes BITs more (or less) likely in countries with FDI flows that are growing over time, such effects will be captured by the country-year trends rather than by the BIT coefficient. At the same time, country-time trends will reduce omitted variable bias, by capturing any log-linear trend in FDI. The alternative approach to control for endogeneity and reverse causality is to instrument the BIT variable in the GMM estimation, following a similar approach as the one used for instrumenting the lagged dependent variable. Also in this case we use lags 2 to 4 of the BIT variable (in levels) to instrument the transformed BIT variable in the equation with orthogonal deviations. The past BIT levels can be shown to be correlated with the differences of the BIT variable to its future means, while being uncorrelated with the transformed error term (Arellano and Bover, 1995; Roodman, 2009b). 
BILATERAL INVESTMENT TREATIES AND FDI: DOES THE SECTOR MATTER?

To summarize, in order to properly take into account the evolution of FDI stocks over time and to tackle the different econometric issues, we will report results for three different econometric specifications, in which we progressively refine our estimation strategy: (1) dynamic OLS fixed effects model, (2) dynamic OLS fixed effects model including country-time trends, and (3) GMM orthogonal transformation in which both the lagged dependent variable and the BIT variable are instrumented.

\section{$5 \quad$ RESULTS}

Table 3, 4 and 5 report our main results. Table 3 shows the estimated effect of BITs on FDI stocks, without allowing the effect to differ across sectors (model A). Results in Table 4 estimates the effects of an additional BIT for each sector separately (model B). In Table 5, the BIT variable is interacted with the degree of sunkness of each sector (model C). Table 6 and A3 in appendix show a number of robustness tests.

Results in Table 3 first of all confirm the strong dependency in FDI stocks over time that we expected. Secondly, the positive coefficients of the BIT variable suggest that the treaties have an overall positive impact on FDI, although the effect is statistically significant at conventional levels only in column (2) (the p-values for BITs in columns (1) and (3) are 0.10 and 0.24 , respectively). Based on specifications (2) and (3), which better address endogeneity, we estimate that ratifying a new BIT increases FDI stocks by about 2 percent in the short run and about 5 to 10 percent in the long run, where these latter values can be calculated as the short run effect divided by one minus the coefficient on the lagged dependent variable.

[Table 3 about here]

A higher monthly wage is associated with an increase in the stock of FDI, suggesting that an increase in purchasing power and labor productivity (and per capita growth in general), rather 
than low labor costs, explain the inflow of foreign investment. Trade openness also has a positive and significant impact on FDI, while political institutional quality and inflation do not appear to have a significant effect on FDI in any of the specifications ${ }^{13}$.

While these results suggest that BITs are generally successful in attracting FDI, the actual purpose of this paper is to analyze whether the effectiveness of BITs varies across sectors. Table 4 shows the estimated effect of BITs for each sector of investment separately. Consistently over all econometric specifications, the estimated coefficients on the BIT variable are the largest for FDI in utilities and real estate, followed by agriculture, banking, and mining (ordered according to the results of the GMM estimation in column (3)), while coefficients on manufacturing and services are always the smallest ones. The effect of BITs on FDI in real estate and utilities is robustly significant over the different empirical specifications. For manufacturing and services, on the contrary, the estimated coefficients are never statistically significant. The estimates for mining and agriculture are positive and larger in magnitude compared to manufacturing and services, but mostly not significantly different from zero. Note that mining and agriculture also have the smallest share in total FDI in our sample (see Table 2) and not all countries are equally endowed with resources for agriculture or mining. If the impact of a BIT varies largely across countries because of different resource endowments, this may explain why the estimate is measured with more error.

The difference between the effect of BITs for utilities, real estate or banking on the one hand versus manufacturing or services on the other hand is significant at the $10 \%$ level. Although for other sectors the point estimates are also larger compared to manufacturing and services, these differences are not statistically significant at conventional levels.

[Table 4 about here] 
As a next step in our analysis, we analyze whether the degree of irreversibility of investments in these economic sectors provide a plausible explanation for the differences in effectiveness of BITs across sectors. We do so by interacting the BIT variable with a proxy for the importance of sunk costs in each sector and we report results in Table 5. In our basic specification we use the capital stock per firm as a proxy, from which we subtract the mean value over all sectors. Table A3 in appendix shows that results are robust to using the capital-labor ratio instead. In all specifications, sectors with a higher degree of sunk costs are found to be more responsive to BITs. The coefficient on the BIT variable should be interpreted as the marginal effect of an additional BIT for a sector with the average level of fixed capital stock per firm. Based on specifications (3) this effect would correspond to an increase in FDI stock by about 2\%, which also corresponds to the estimated common BIT effect in Table 3. We calculate the effect of a BIT for a sector with a capital stock per firm at the lowest decile to be $0.9 \%$ and not significantly different from zero, while for a sector with a capital stock per firm at the highest decile, an additional BIT is estimated to increase the FDI stock by $3.4 \%$, and this effect is highly significant.

Overall, these results confirm our initial hypotheses and in Table 6 we check their robustness. In the first two columns of Table 6, we report the results when using the date of signature rather than the date of ratification to construct the BITs variable. ${ }^{14}$ As expected, the BITs coefficients get smaller when using the date of signature and they all lose statistical significance when looking at the different sectors separately (column (1)), although the variation in the magnitude of coefficients across sectors still corresponds to the earlier results. We still find that the effect of signing an extra BIT increases significantly with the importance of sunk costs in the sector (column (2)), but also in this case the coefficient on the interaction term is smaller compared to using the number of BITs ratified. 
BILATERAL INVESTMENT TREATIES AND FDI: DOES THE SECTOR MATTER?

When we use the number of BITs ratified with the top 15 capital exporters (columns (3) and (4)), we find larger coefficients than in the basic specifications, again in line with our expectations. BITs are found to have the largest effects on investments in utilities and real estate (with a p-value of 0.11 for the latter). Column (4) also confirms that a higher degree of sunk costs corresponds to a larger effect of an additional BIT, and if we compare the coefficient to the one reported in Table 5 (column (2)), we see that the effect is much larger when it concerns a BIT with a major capital exporter.

\section{[Table 5 about here]}

\section{[Table 6 about here]}

As a last check, we test whether different levels of irreversibility affect the effectiveness of BITs also within the manufacturing sector, across industries characterized by different degrees of sunkness (Table 6, column (5)) ${ }^{15}$. Similarly to what we did for the analysis by sectors, we calculate the capital costs per firm for each manufacturing industry and interact this measure with the BIT variable. The estimates in the last column (5) of Table 6 indicate that for the average level of sunkness, the effect of a BIT on investment in manufacturing is close to zero (which corresponds to the results for manufacturing in Table 4). Yet, our results provide some suggestive evidence that for manufacturing industries with a high degree of sunk costs BITs do matter: for industries operating at the $90^{\text {th }}$ percentile of the average fixed capital stock, ratifying an additional BIT increases FDI by about $1 \%$ (p-value of 0.24$)^{16}$.

Overall, our results suggest that BITs have positive effects on FDI in general, which is in line with the recent literature. However, our results also provide the first empirical evidence that the effectiveness of BITs varies significantly across the sector of investment. We find that FDI in utilities, real estate and to a lesser extent in banking reacts most strongly to a new BIT, while for 
manufacturing and services the estimated effects are much smaller and not significantly different from zero. One additional BIT is estimated to increase the FDI stock in utilities by 2.5 to $4.1 \%$, in real estate by 1.6 to $3.3 \%$ and in banking by about 0.9 to $2.3 \%$. For agriculture, coefficients point to an effect of 0.5 to $2.5 \%$. The effects in manufacturing and services are significantly smaller compared to utilities and banking. For mining the estimated effect of BITs is lower and less robust than we would have expected based on our conceptual arguments (about 0.6 to $1.7 \%$ ). Especially given the political sensitivity and the history of expropriations in the mining sector, one would expect FDI in this sector to react more strongly to a new BIT. This might however be related to the nature of our sample, which does not include major mineral or oil exporting countries. Moreover, mining in Eastern Europe mainly consists of coal mines, concentrated in few countries. The different nature of mineral mining that characterizes for instance certain resource-rich African countries may result in a different reaction to BITs. Hence, a stronger impact of BITs on mining investments may potentially be found using a different sample, which includes a larger number of countries with considerable natural resource endowments and mining opportunities. In this regard, it is interesting to note that in a study on the effectiveness of BITs for 83 developing host countries, Busse et al. (2010) find that the size of the BITs coefficient is lower when excluding the resourceintensive host countries. While the authors of this study find this result surprising (they argue that the availability of natural resources should be such an important determinant of FDI that it would rule out the effect of a BIT), their finding supports our hypothesis that investments in the mining sector are particularly responsive to improved protection through BITs because of their high sensitivity to expropriation and policy reversals.

Interacting the BIT variable with a proxy for sunkness in each sector suggests that higher sunk costs at least partially explains why FDI is more responsive to the signing of a BIT in certain 
sectors rather than in others. These results support the hypothesis that investment projects with large sunk costs are more sensitive to risk and more attractive for expropriation by the government and, as a result, more responsive to the protection provided by BITs.

\section{CONCLUSION}

Developing and transition countries have increasingly engaged in the signing of bilateral investment treaties in order to attract FDI, based on the widely shared view that FDI can contribute significantly to economic development and poverty reduction. However, the degree to which foreign investments can be expected to generate employment, offer access to international technology and know-how, and ultimately create growth, varies considerably depending on the type of investment. As phrased in the 2012 World Investment Report: "Policymakers should be aware of the different types [of foreign investment], each with distinct development impacts" and "the potential contribution of foreign investment [...] should guide investment policy and targeting effects" (UNCTAD, 2012a, p. 112-113). It is therefore important to understand not only whether bilateral investment treaties effectively succeed in attracting foreign investments, but also which types of investments they are able to attract.

While several recent studies have addressed the more general question on the effectiveness of BITs, this paper represents the first attempt to empirically study the heterogeneous effect that BITs may have across different types of investments. We argue that BITs can be expected to be most effective in those sectors of the economy characterized by large sunk costs, relatively low levels of firm-specific know-how and in sectors that are politically sensitive to foreign ownership. Based on a sample of sectorally disaggregated FDI data for 13 transition countries in Central and Eastern Europe and the Former Soviet Union, we find that BITs are especially effective for attracting FDI in the sectors of utilities and real estate. For foreign investments in manufacturing 
and services, BITs seem not to play a major role in investment decisions. These different effects across samples can at least partially be explained by the different degree of sunkness of investments in these sectors.

The small sample of countries in this study limits the external validity of our findings, and the impact of BITs on FDI in the mining sector may be very different in countries with large amounts of FDI directed to the mining of high value minerals. Performing a similar analysis on a broader set of countries would therefore be desirable, before extrapolating our conclusions to other settings. Nevertheless, given current data limitations, our results are important in the sense that they show for the first time that the provision of investment protection has heterogeneous effects across sectors of investments. Given the considerable differences in the development impact that can be expected from FDI in different sectors, our results question whether BITs are the most effective tool to attract those types of investments that are most beneficial for the development of the host economy.

\section{REFERENCES}

Alfaro, L., \& Charlton, A. (2007). Growth and the Quality of Foreign Direct Investment: Is All FDI Equal? Harvard Business School Working Paper 07-072.

Arellano, M., \& Bover, O. (1995). Another Look at the Instrumental Variables Estimation of ErrorComponents Models. Journal of Econometrics, 68, 29-51.

Arellano, M., \& Bond, S. (1991). Some Tests of Specification for Panel Data, Monte Carlo Evidence and an Application to Employment Equations. The Review of Economic Studies, 58, 277-297. 
BILATERAL INVESTMENT TREATIES AND FDI: DOES THE SECTOR MATTER?

Amendolagine V., Boly, A., Coniglio N.D., Prota, F. \& Seric, A. (2013). FDI and Local Linkages in Developing Countries: Evidence from Sub-Saharan Africa, World Development, 50, 4156.

Aykut, D., \& Sayek, S. (2007). The Role of the Sectoral Composition of FDI on Growth. In: L. Piscitello and G.D. Santangelo (Eds.).Do Multinationals Feed Local Development and Growth (Amsterdam: Elsevier).

Asiedu, E. (2004). The Determinants of Employment of Affiliates of US Multinational Enterprises in Africa. Development Policy Review, 22, 371-379.

Berger, A., Busse, M., Nunnenkamp, P., \& Roy, M. (2013). Do Trade and Investment Agreements Lead to More FDI? Accounting for Key Provisions Inside the Black Box. International Economics and Economic Policy, 10, 247-275.

Blonigen, B.A. (2005). A Review of the Empirical Literature on FDI Determinants, Atlantic Economic Journal, 33, 383-403.

Busse, M., Königer, J., \& Nunnenkamp, P. (2010). FDI Promotion Through Bilateral Investment Treaties: More Than a Bit? Review of World Economics, 146, 147-177.

Büthe, T., \& Milner, H.V. (2008). The Politics of Foreign Direct Investment into Developing Countries: Increasing FDI through International Trade Agreements? American Journal of Political Science, 52, 741-762.

Cabral, L. (1995). Sunk Costs, Firm Size and Firm Growth. The Journal of Industrial Economics, $161-172$.

Chakrabarti, A. (2001). The Determinants of Foreign Direct Investments: Sensitivity Analyses of Cross-Country Regressions. Kyklos, 54, 89-114. 
BILATERAL INVESTMENT TREATIES AND FDI: DOES THE SECTOR MATTER?

Chakraborti, C., \& Nunnenkamp P. (2008). Economic Reforms, FDI and Economic Growth in India: A Sector Level Analysis, World Development, 36, 1192-1212.

Colen, L., Maertens, M., \& Swinnen, J. (2009). Foreign Direct Investment as an Engine for Economic Growth and Human Development: A Review of the Arguments and Empirical Evidence. Human Rights \& International Legal Discourse, 3, 177-227.

Crespo, N., \& Fontoura M.O. (2007). Determinant Factors of FDI Spillovers - What Do We Really Know? World Development, 35, 410-425

De Mello L. R. Jr. (1997). Foreign Direct Investments in Developing Countries and Growth: A Selective Survey, Journal of Development Studies, 34, 1-34.

Duncan, R. (2006). Price or Politics? An Investigation of the Causes of Expropriation. The Australian Journal of Agricultural and Resource Economics, 50, 85-101.

Eaton, J., \& Gersovitz, M. (1984). A Theory of Expropriation and Deviations from Perfect Capital Mobility. The Economic Journal. 50, 85-101.

Egger, P., \& Merlo, V. (2007). The Impact of Bilateral Investment Treaties on FDI Dynamics. The World Economy, 30, 1536-1549.

Egger, P., \& Merlo, V. (2012). BITs Bite: An Anatomy of the Impact of Bilateral Investment Treaties on Multinational Firms. Scandinavian Journal of Economics, 114, 1240-1266.

Elkins, Z., Guzman, A., \& Simmons, B. (2006). Competing for Capital: The Diffusion of Bilateral Investment Treaties, 1960-2000. International Organization, 60, 811-846.

Engel, E., \& Fischer, R.D. (2010). The Natural Resources Trap: Private Investment without Public Commitment. In: Optimal resource extraction contracts under threat of expropriation, pp. 161-196. Cambridge, MA: MIT Press. 
BILATERAL INVESTMENT TREATIES AND FDI: DOES THE SECTOR MATTER?

EU KLEMS (2011). EU KLEMS Growth and Productivity Accounts, March 2011 update, www.euklems.net

Freedom House (2012). Freedom in the World: Country Ratings (1972-2011). (www.freedomhouse.org)

Ghosal, V., \& Loungani, P. (2000). The Differential Impact of Uncertainty on Investment in Small and Large Businesses. The Review of Economics and Statistics, 82, 338-343.

Gschwandtner, A., \& Lambson, V. E. (2002). The effects of sunk costs on entry and exit: evidence from 36 countries. Economics Letters, 77, 109-115.

Hajzler, C. (2012). Expropriation of Foreign Direct Investments: Sectoral Patterns from 1993 to 2006. Review of World Economics, 148, 119-149.

Hallward-Driemeier, M. (2003). Do Bilateral Investment Treaties Attract Investment? Only a Bit... and They Could Bite. World Bank Research Working Paper 3121, Washington DC: The World Bank.

Henisz, W.J. (2002). Politics and International Investment: Measuring Risks and Protecting Profits. Northampton, MA: E. Elgar.

Henisz, W.J. (2006). Polcon_2005 Codebook. (http://www-management.wharton.upenn.edu /henisz/ (11 April 2007) )

ILO (2012). LABORSTA Labour Statistics Database. International Labour Organization, Geneva.

Iwasaki, I., \& Tokunaga, M. (2014). Macroeconomic Impacts of FDI in Transition Economies: A Meta-Analysis. World Development, 61, 53-69.

Iršová, Z., \& Havránek T. (2013). Determinants of Horizontal Spillovers from FDI: Evidence from a Large Meta-Analysis, World Development, 42, 1-15. 
BILATERAL INVESTMENT TREATIES AND FDI: DOES THE SECTOR MATTER?

Javorcik, B. (2004). Does Foreign Direct Investment Increase the Productivity of Domestic Firms? In Search of Spillovers through Backward Linkages. American Economic Review, 94, 605627.

Jodice, D.A. (1980). Sources of Change in Third World Regimes for Foreign Direct Investment, 1968-1976. International Organization, 34, 177-206.

Kerner, A. (2009). Why Should I Believe You? The Costs and Consequences of Bilateral Investment Treaties. International Studies Quarterly, 53, 73-102.

Khan, M.S., \& Senhadji, A.S. (2001). Thresholds Effects in the Relationship between Inflation and Growth. IMF Staff Papers, 148, 1-21.

Kobrin, S. J. (1980). Foreign Enterprise and Forced Divestment in LDCs. International Organization, 34, 65-88.

Kobrin, S. J. (1984). Expropriation as an Attempt to Control Foreign Firms in LDCs: Trends from 1960-1979. International Studies Quarterly, 28, 329-348.

Lambson, V. E., \& Jensen, F. E. (1998). Sunk costs and firm value variability: theory and evidence. American Economic Review, 307-313.

Li, Q. (2009). Democracy, Autocracy, and Expropriation of Foreign Direct Investment. Comparative Political Studies, 42, 1098-1127.

Lipsey, R.E. (2000). Inward FDI and Economic Growth in Developing Countries. Transnational Corporations, 9, 67-95.

Mayer-Foulkes, D., \& Nunnenkamp, P. (2009). Do Multinational Enterprises Contribute to Convergence or Divergence? A Disaggregated Analysis of US FDI. Review of Development Economics, 13, 304-318. 
BILATERAL INVESTMENT TREATIES AND FDI: DOES THE SECTOR MATTER?

Minor, M. S. (1994). The Demise of Expropriation as an Instrument of LDC Policy, 1980-1992. Journal of International Business Studies, 25, 177-188.

Neumayer, E. (2006). Self-interest, Foreign Need, and Good Governance: Are Bilateral Investment Treaty Programs Similar to Aid Allocation? Foreign Policy Analysis, 2, 245268.

Neumayer, E., \& Spess, L. (2005). Do Bilateral Investment Treaties Increase Foreign Direct Investment to Developing Countries? World Development, 33, 1567-1585.

Nickell, S. (1981). Biases in Dynamic Models with Fixed Effects. Econometrica, 49, 1417-1425.

$\begin{array}{llllll}\text { Nunnenkamp, } & \text { P. } & \text { (2004). } & \text { To } & \text { What }\end{array}$ Foreign Direct Investment Help Achieve International Development Goals? World Economy, 27, 657-677.

Nunnenkamp, P., \& Spatz, J. (2004). Foreign Direct Investment and Economic Growth in Developing Countries: How Relevant Are Host-Country and Industry Characteristics? Transnational Corporations, 13, 53-86.

OECD (2002). Foreign Direct Investment for Development: Maximising Benefits, Minimizing Costs. OECD, Paris.

Pennings, E., \& Sleuwagen, L. (2000). International Relocation: Firm and Industry Determinants. Economics Letters, 67, 179-186.

Polity IV (2012). POLITY IV Political Regime Characteristics and Transitions, 1800-2010. (http://www.systemicpeace.org/polity/polity4.htm)

Raff, H. (1992). A Model of Expropriation with Asymmetric Information. Journal of International Economics, 33, 245-265. 
BILATERAL INVESTMENT TREATIES AND FDI: DOES THE SECTOR MATTER?

Reisman, W.M., \& Sloane, R.D. (2004). Indirect Expropriation and its Valuation in the BIT Generation. British Yearbook of International Law, 75, 115-150.

Roodman, D. (2009a). A Note on the Theme of Too Many Instruments. Oxford Bulletin of Economics and Statistics, 71, 135-158.

Roodman, D. (2009b). How to Do Xtabond2: An Introduction to "Difference" and "System" GMM in STATA, The Stata Journal, 9, 86-136.

Shafer, M. (2009). Capturing the Mineral Multinationals: Advantage or Disadvantage? International Organization, 37, 93-119.

Simmons, B.A. (2000). International Law and State Behavior: Commitment and Compliance in International Monetary Affairs. The American Political Science Review, 94, 819-835.

Tobin, J.L., \& Rose-Ackerman, S. (2011). When BITs Have Some Bite: The Political-Economic Environment for Bilateral Investment Treaties. Review of International Organizations, 6, $1-32$.

Truitt, F. J. (1970). Expropriation of Foreign Investment: Summary of the Post-World War II Experience of American and British Investors in the Less Developed Countries. Journal of International Business Studies, 1, 21-34.

UNCTAD (1998). World Investment Report 1998. Trends and Determinants. New York and Geneva: United Nations.

UNCTAD (2009). The Role of International Investment Agreements in Attracting Foreign Direct Investment to Developing Countries. New York and Geneva: United Nations.

UNCTAD (2001). World Investment Report 2001. Promoting Linkages. New York and Geneva: United Nations. 
BILATERAL INVESTMENT TREATIES AND FDI: DOES THE SECTOR MATTER?

UNCTAD (2010). World Investment Report 2010. Investing in a Low-Carbon Economy. New York and Geneva: United Nations.

UNCTAD (2012a). World Investment Report 2012. Towards a New Generation of Investment Policies. New York and Geneva: United Nations.

UNCTAD (2012b). IIA database (www.unctad.org/iia), New York and Geneva, United Nations.

UNCTAD (2012c). FDI/TNC database. New York and Geneva, United Nations.

Vandevelde, K. J. (1998). Investment Liberalization and Economic Development: The Role of Bilateral Investment Treaties. Columbia Journal of Transnational Law, 36, 501-527.

Vernon, R. (1971). Sovereignty at Bay: The Multinational Spread of US Enterprises. New York: Basic Books.

WIIW (2010). WIIW Handbook of Statistics 2010: Central, East and Southeast Europe, Vienna Institute for International Economic Studies, Vienna, Austria.

World Bank (2012). World Development Indicators (http://data.worldbank.org)

Xu, B. (2000). Multinational Enterprises, Technology Diffusion, and Host Country Productivity Growth. Journal of Development Economics, 62, 477-493. 


\section{BILATERAL INVESTMENT TREATIES AND FDI: DOES THE SECTOR MATTER?}

\section{ENDNOTES}

${ }^{1}$ For an overview of the literature on the impact of FDI on economic growth see De Mello (1997), Lipsey (2000) and Colen et al. (2009). Recently, Iwasaki and Tokunaga (2014) performed a meta-analysis focusing on Central and Eastern Europe and the former Soviet Union, finding large positive growth effects.

${ }^{2}$ Other major determinants of FDI are market size, income and labor costs, but these are typically difficult for governments to alter in the short run (see Blonigen (2005) and Chakrabarti (2001) for a detailed theoretical and empirical discussion of the determinants of FDI).

${ }^{3}$ Although the details of the treaties vary from case to case, all BITs include the same key elements. Berger et al. (2013) look into the specific provisions contained in each BIT, but find no difference in investors' reaction.

${ }^{4}$ ICSID was established in 1966 as a member of the World Bank Group. The primary purpose of ICSID is to provide facilities for conciliation and arbitration of international investment disputes between governments and private foreign investors.

${ }^{5}$ The number of expropriation acts was collected by Kobrin (1984), Minor (1994) and Hajzler (2012) from reports of expropriations published in a wide range of periodicals. Note that these studies do not consider expropriations in the real estate sector. Note that Table 1 only includes direct expropriations of foreign investments, which took mainly place in the 1960s and 1970s (corresponding to the period of colonial independence). More recently, indirect expropriations are relatively more frequent (Reisman and Sloane, 2004). Therefore, Table 1 likely understates the total number of expropriations, especially for sectors that are relatively more sensitive to adverse regulatory changes rather than to direct expropriations, such as the banking sector.

${ }^{6}$ Note that the disputes laid down at the international arbitration courts also include 'indirect expropriations', which likely explains why the share of the banking sector (typically more sensitive to indirect expropriations) is higher than its share in Table 1, which only considers direct expropriations. 


\section{BILATERAL INVESTMENT TREATIES AND FDI: DOES THE SECTOR MATTER?}

7 The US Bureau of Economic Analysis (BEA) provides sectorally disaggregated information for US outward FDI, but - besides only being representative for US outgoing FDI - the data on FDI in mining and utilities contain a very large number of missing or non-disclosed observations while these are precisely two sectors of primary importance for testing our hypothesis.

${ }^{8}$ In a survey among managers, BITs were reported to be amongst the most important decision factors when undertaking FDI in transition countries, and more important than for other countries (UNCTAD, 2009). Moreover, transition countries are more than disproportionally represented in investor-state disputes: by 2007 they had been involved in $23 \%$ of all investor-state disputes, while having received only $12 \%$ of the developing countries' FDI stock (UNCTAD, 2012b\&c). Also, Busse et al. (2010) find a smaller effect of BITs when excluding the transition countries of Central and Eastern Europe from the sample. They argue that BITs may have been more effective in these countries, because of the lack credibility of unilateral measures taken and the higher political risk during the period of regime change.

${ }_{9}^{9}$ Since the Political Constraints Index is only available till the year 2007, we set the values for 2008 and 2009 equal to those in 2007. Our results are robust to the use of alternative indicators such as the Freedom House Index (FHI) (Freedom House, 2012), or the Polity 2 variable (Polity IV, 2012).

${ }^{10}$ Because data are missing on the number of firms active in the real estate sector in Germany, we replaced the proxy for the real estate sector by its corresponding value in The Netherlands. Our results are robust to excluding the real estate sector entirely, or using the value in The Netherlands for all sectors. Note that the capital-labor ratio, which is based on the accounts of domestic companies in Germany, may be a slight overestimation of the true capital-labor ratio for the activities by foreign-owned firms in Central and Eastern Europe because of the relatively lower labor cost in these countries. We tested the robustness of our results to using the capital-labor ratio for Czech Republic (which in turn might be an underestimation) and found all our conclusions to remain valid.

${ }^{11}$ For example, 8 countries in our sample accessed the EU in 2005 and two countries followed later. Year dummies largely account for this. Our results are robust to including post-EU-agreement and post-EU-accession dummies. 


\section{BILATERAL INVESTMENT TREATIES AND FDI: DOES THE SECTOR MATTER?}

These variables are found not to contribute significantly to explaining foreign investment flows and are therefore not included in the final model.

12 The orthogonal deviations transformation removes the fixed effects by subtracting from each observation in $\mathrm{t}=1, \ldots, \mathrm{T}-1$, the mean of all the remaining future observations. This minimizes data loss compared to the more commonly used first difference transformation in which both $\Delta y_{t}$ and $\Delta y_{t+1}$ are missing for every missing value of $y_{t}$. Arellano and Bover (1995) also proposed a system GMM approach in which in addition lagged firstdifferences are used as instruments for the levels. However, the last approach imposes the additional assumption of stationarity of the dependent variable (Roodman, 2009b), which is unlikely to hold for FDI stocks in a period of increasing FDI inflows.

${ }^{13}$ Removing these variables from the regression equation does not significantly affect the results. Also including the linear and squared term of the inflation variable instead of its logarithm does not alter the results.

${ }^{14}$ We use the dynamic fixed effects formulation including country year trends for the alternative specifications reported in Table 6, but our main conclusions also hold for the GMM specifications.

15 The limited size of our sample does not allow to estimate an industry-specific BIT effect, as we did for the sectors, therefore only the model with the BIT variable interacted with the degree of sunkness was estimated. Robustness of these industry-level results to using the GMM specifications could not be tested in a reliable way as the Sargan/Hansen tests pointed to severe problems of instrument validity.

${ }^{16}$ Note that the lack of statistical significance of these estimates is highly related to the first years of the sample (for which data are only available for a limited number of industries for Latvia, Lithuania and Slovenia). When removing the first three years of the sample (reducing the sample by just 36 observations, from 1268 to 1232 ), the interaction term of the BIT variable with the sunkness proxy becomes highly significant, with an associated pvalue of 0.01 . However, for consistency with the previous analysis, we choose to keep the same sample selection and to report the most conservative estimates. 


\section{APPENDIX}

Table A1. Overview of countries and years covered in the dataset.

\begin{tabular}{ll}
\hline Country & Years \\
\hline Bulgaria & $1999-2009$ \\
Croatia & $2000-2008$ \\
Czech Republic & $1997-2005$ \\
Estonia & $1997-2009$ \\
Hungary & $1998-2008$ \\
Latvia & $1994-2009$ \\
Lithuania & $1995-2009$ (a) \\
Macedonia, FYR & $1997-2008$ \\
Poland & $1996-2008$ \\
Romania & $2003-2008$ \\
Slovak Republic & $1996-2007$ \\
Slovenia & $1994-2007$ \\
Ukraine & $2001-2009$ \\
\hline
\end{tabular}

(a) Years 1999, 2001 and 2003 are missing. 
Table A2. NACE codes of economic sectors and manufacturing industries considered in the analysis.

\begin{tabular}{|c|c|c|}
\hline Sector/Industry & NACE code (Rev.1) & Description \\
\hline Agriculture & $\mathrm{A}, \mathrm{B}$ & Agriculture, hunting, forestry and fishing \\
\hline Banking & $\mathrm{J}$ & Financial intermediation \\
\hline Real estate & K & Real estate, renting and business activities \\
\hline Manufacturing & $\mathrm{D}$ & Manufacturing \\
\hline Food & $d a$ & Food products, beverages and tobacco \\
\hline Textiles \& leather & $d b \_d c$ & $\begin{array}{l}\text { Textiles and textile products, leather and } \\
\text { leather products }\end{array}$ \\
\hline Wood & $d d$ & Wood and wood products \\
\hline Paper & de & $\begin{array}{l}\text { Pulp, paper, paper production, publishing } \\
\text { and printing }\end{array}$ \\
\hline $\begin{array}{l}\text { Coke \& ref. } \\
\text { petroleum }\end{array}$ & $d f$ & $\begin{array}{l}\text { Coke, refined petroleum products and } \\
\text { nuclear fuel }\end{array}$ \\
\hline Chemicals & $d g$ & $\begin{array}{l}\text { Chemicals, chemical products and man- } \\
\text { made fibres }\end{array}$ \\
\hline Rubber \& plastic & $d h$ & Rubber and plastic products \\
\hline Other mineral prod. & $d i$ & Other non-metallic mineral products \\
\hline Basic metals & $d j$ & $\begin{array}{l}\text { Basic metals and fabricated metal } \\
\text { products }\end{array}$ \\
\hline Machinery n.e.c. & $d k$ & Machinery and equipment n.e.c. \\
\hline Electr.\&optical eq. & $d l$ & Electrical and optical equipment \\
\hline Transport & $d m$ & Transport equipment \\
\hline Mining & $\mathrm{C}$ & Mining and quarrying \\
\hline Services & $\mathrm{G}, \mathrm{H}, \mathrm{I}$ & $\begin{array}{l}\text { Wholesale, retail trade, reparations of motor } \\
\text { vehicles etc.; Hotels, restaurants; Transport, } \\
\text { storage, communication }\end{array}$ \\
\hline Utilities & E & Electricity, gas and water supply \\
\hline
\end{tabular}


Table A3. Regression results: BITs variable interacted with the degree of sunkness using the capital-labor ratio proxy

\begin{tabular}{|c|c|c|c|}
\hline & (1) & (2) & (3) \\
\hline & Dynamic FE & Dynamic FE, & GMM, BIT \\
\hline & & country trends & endogenous \\
\hline FDI stock, Ln & $0.655^{* * * * * 4}$ & $0.593^{\text {***** }}$ & $0.819^{\text {**:N }}$ \\
\hline & $(0.0423)$ & $(0.0419)$ & $(0.0880)$ \\
\hline BITs in force & $0.00879^{*}$ & $0.0227^{* *}$ & 0.0245 \\
\hline & $(0.00528)$ & $(0.0109)$ & $(0.0171)$ \\
\hline BITs*Sunkness & $0.207^{* *}$ & $0.255^{* * *}$ & $0.199^{*}$ \\
\hline & $(0.0802)$ & $(0.0660)$ & $(0.121)$ \\
\hline Monthly wage, Ln & $0.415^{* * * *}$ & 0.225 & $0.481^{* *}$ \\
\hline & $(0.152)$ & $(0.178)$ & $(0.189)$ \\
\hline Inflation (\%), Ln & 0.0275 & -0.0161 & 0.0226 \\
\hline & $(0.0187)$ & (0.0199) & $(0.0193)$ \\
\hline Political Constraints & 0.215 & 0.0737 & 0.197 \\
\hline & $(0.140)$ & $(0.156)$ & $(0.204)$ \\
\hline Trade (\% GDP), Ln & $0.409^{* * *}$ & $0.467^{*}$ & $0.389^{* *}$ \\
\hline & $(0.185)$ & $(0.254)$ & $(0.185)$ \\
\hline Observations & 853 & 853 & 765 \\
\hline Country-sector fixed effects & $\mathrm{Y}$ & $\mathrm{Y}$ & $\mathrm{Y}$ \\
\hline Time dummies & $\mathrm{Y}$ & $\mathrm{Y}$ & $\mathrm{Y}$ \\
\hline Country-time trends & $\mathrm{N}$ & $\mathrm{Y}$ & $\mathrm{N}$ \\
\hline Number of instruments & & & 27 \\
\hline $\operatorname{AR}(2)(p$-value $)$ & & & 0.651 \\
\hline Sargan test ( $p$-value) & & & 0.254 \\
\hline Hansen test ( $p$-value) & & & 0.271 \\
\hline$R^{2}$ & 0.861 & 0.871 & 0.914 \\
\hline
\end{tabular}

BITs refers to the number of ratified BITs. Sunkness is proxied by the capital-labor ratio.

Robust standard errors in parentheses. ${ }^{*} p<0.10,{ }^{* *} p<0.05,{ }^{* * * *} p<0.01$. 

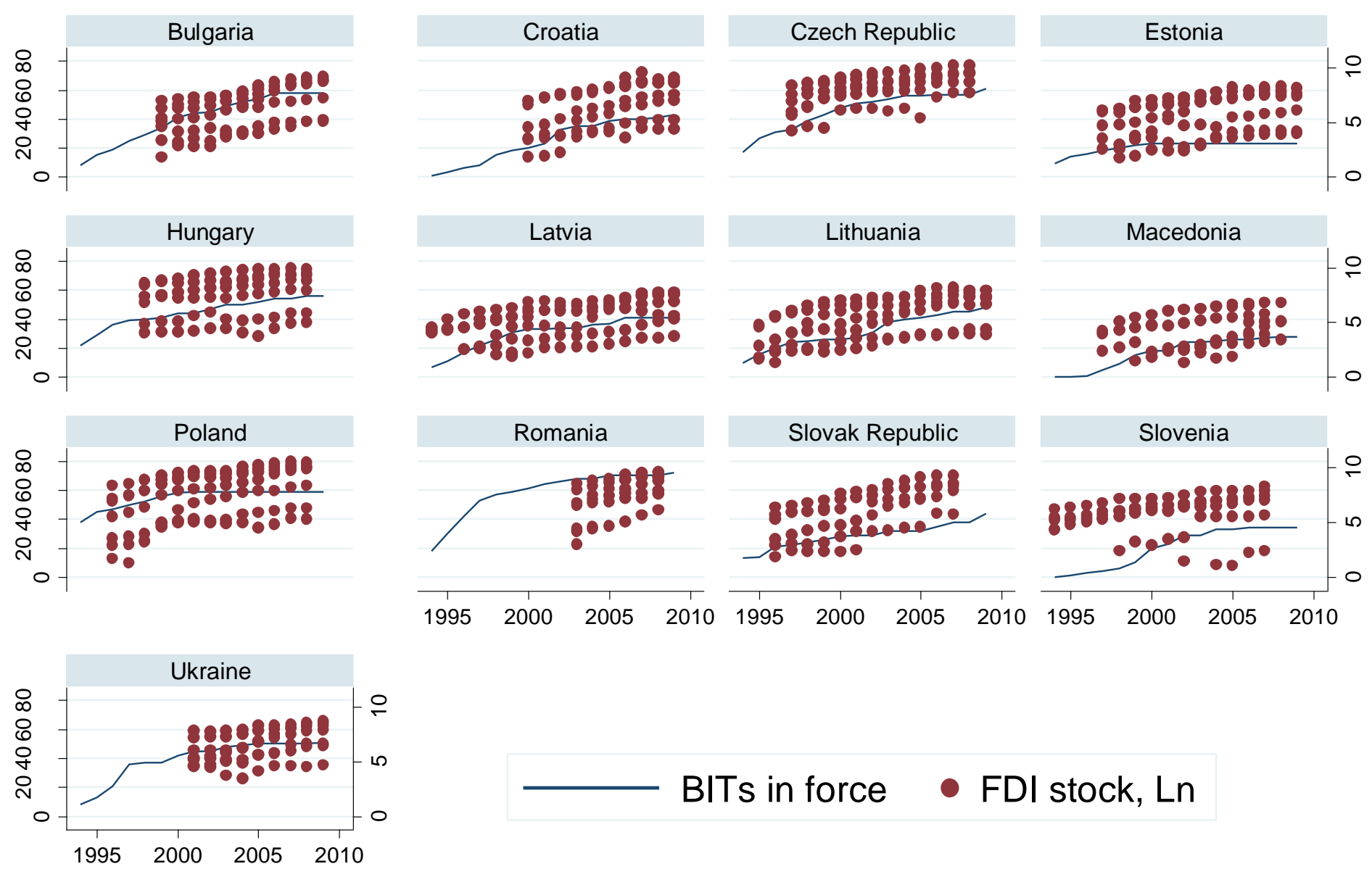

Figure A1. Number of BITs in force (left axis) and logarithm of inward FDI stocks (million euros) for each sector (right axis) by country (1994-2009). 


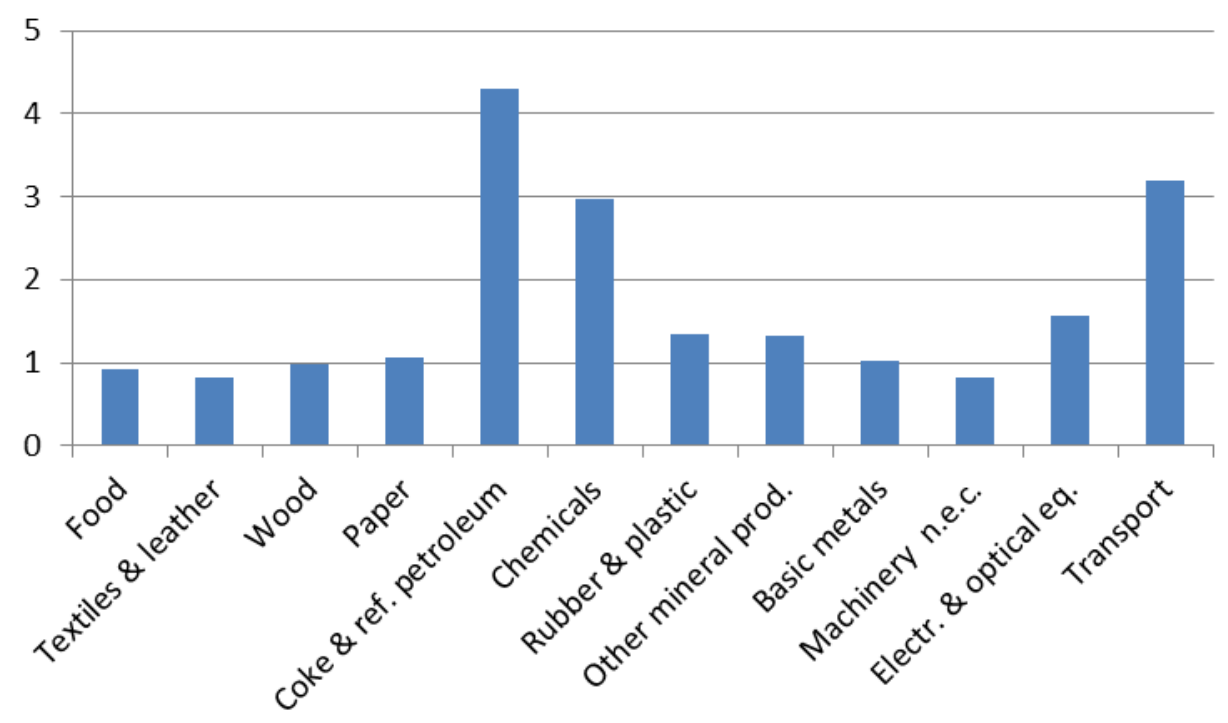

Figure A2 a. Fixed capital stock per firm (in logarithm) by manufacturing industry (Germany, 1991-1997)

The fixed capital stock per firm is calculated as the ratio of the real fixed capital stock (in million EUR) to the number of firms in each manufacturing industry. Source: EU KLEMS (2011).

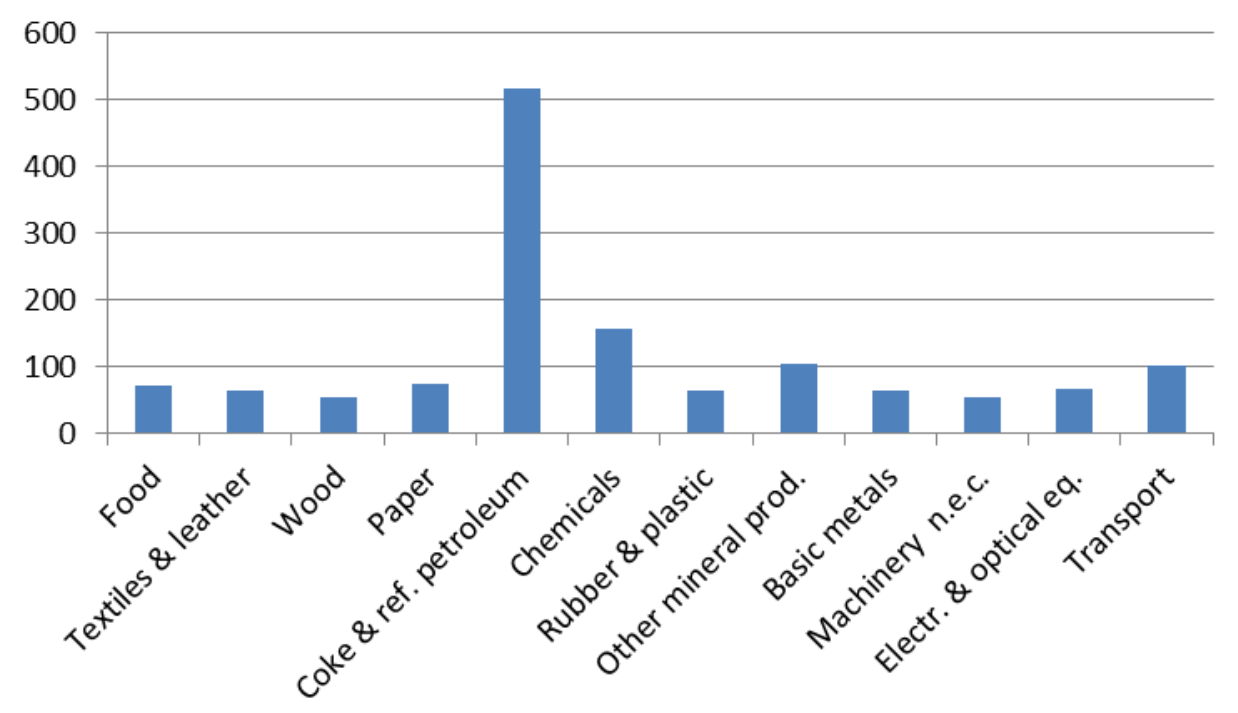

Figure A2 b. Capital-labor ratio, by manufacturing industry (Germany, 1997-2007).

The capital-labor ratio of each manufacturing industry is calculated as the ratio of the real fixed capital stock (in million EUR) to the number of engaged persons (in thousands). Source: EU KLEMS (2011). 


\section{FIGURES}

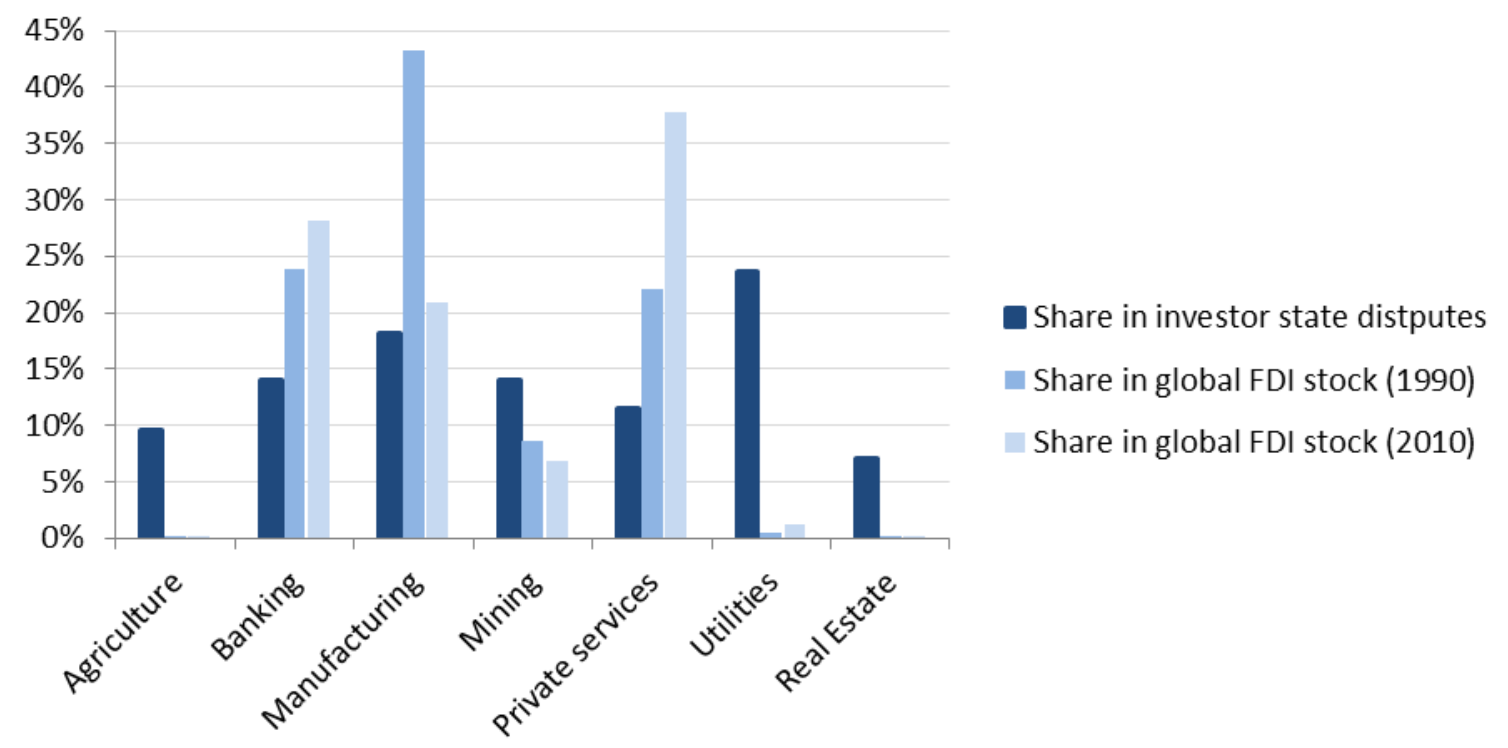

Figure 1. Sector shares in total FDI stock (1990 and 2010) and sector shares investor state disputes per sector $(1987$ - 2010)

Source: Authors' calculations based on the IIA database for investor state disputes (UNCTAD, 2012b) and on UNCTAD (2010) for data on sector shares in global FDI stock in the years 1990 and 2010. 


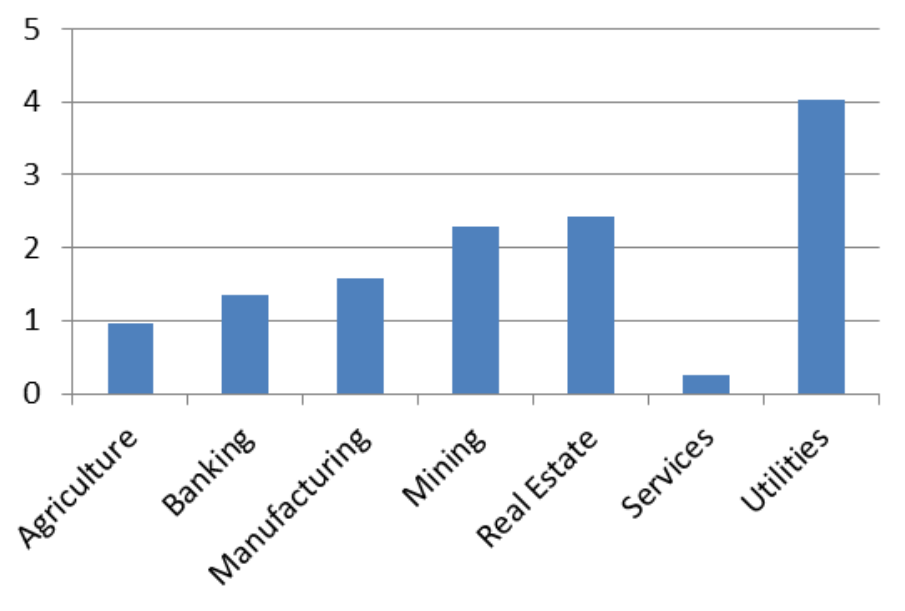

Figure 2a. Fixed capital stock per firm (in logarithm) by sector (Germany, 1991-1997)

The fixed capital stock per firm is calculated as the ratio of the real fixed capital stock (in million EUR) to the number of firms in each sector.

Source: EU KLEMS (2011)

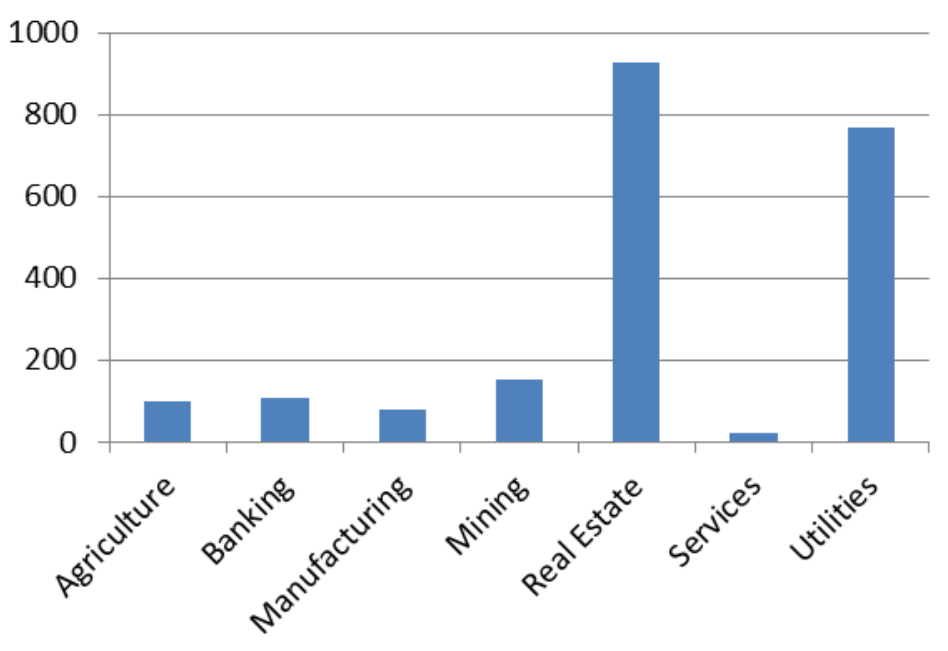

Figure 2b. Capital-labor ratio, by sector (Germany, 1997-2007).

The capital-labor ratio of each sector is calculated as the ratio of the real fixed capital stock (in million EUR) to the number of engaged persons (in thousands).

Source: EU KLEMS (2011) 


\section{TABLES}

Table 1. Sector and Time Patterns of Expropriation Acts in Developing Countries: 1960-2006

$1960-69 \quad 1970-79 \quad 1980-89 \quad 1990-99 \quad 2000-06$

\begin{tabular}{|c|c|c|c|c|c|}
\hline \multicolumn{6}{|c|}{ Share in total expropriation acts $(\%)$} \\
\hline Primaries & 36.8 & 40.4 & 52.9 & 31.8 & 48.1 \\
\hline Agriculture & 8.8 & 8.7 & 36.3 & 0.0 & 11.1 \\
\hline Mining & 11.8 & 12.3 & 0.0 & 22.7 & 18.5 \\
\hline Petroleum & 16.2 & 19.4 & 17.6 & 9.1 & 18.5 \\
\hline Manufacturing & 25.7 & 27.4 & 23.5 & 13.6 & 14.8 \\
\hline Services & 37.5 & 31.4 & 23.5 & 54.5 & 37.0 \\
\hline Banking & 12.5 & 11.6 & 0.0 & 0.0 & 0.0 \\
\hline Communication & 1.5 & 2.4 & 0.0 & 0.0 & 7.4 \\
\hline Trade & 7.4 & 4.0 & 5.9 & 4.5 & 3.7 \\
\hline Transportation & 5.9 & 3.3 & 5.9 & 4.5 & 3.7 \\
\hline Utilities & 10.3 & 4.5 & 0.0 & 18.2 & 11.1 \\
\hline Other services & 0.0 & 3.8 & 11.8 & 18.2 & 11.1 \\
\hline \multicolumn{6}{|c|}{ Total number of expropriation acts } \\
\hline & 136 & 423 & 17 & 22 & 27 \\
\hline
\end{tabular}

Taken from Hajzler (2012). Sources: Kobrin (1984), Minor (1994) and Hajzler (2012). 
Table 2. Sector shares in total FDI stock for the countries in our sample (average over 1994-2009)

\begin{tabular}{lcrrr}
\hline Sector & $\begin{array}{c}\text { Total inward FDI } \\
\text { stock (million euros) }\end{array}$ & \multicolumn{2}{c}{ Share in total FDI stock (\%) } \\
\hline Agriculture & Mean & Mean & Minimum & Maximum \\
\hline Banking & 131 & 1.0 & 0.2 & 3.3 \\
Manufacturing & 3,192 & 19.8 & 5.5 & 50.6 \\
Mining & 5,769 & 35.4 & 11.2 & 70.9 \\
Real Estate & 209 & 1.4 & 0.0 & 13.5 \\
Services & 2,186 & 11.2 & 1.1 & 31.6 \\
Utilities & 4,118 & 28.4 & 13.0 & 60.8 \\
\hline Source: Author's calculations based on WIIW & 771 & 4.4 & 0.4 & 17.4 \\
\hline
\end{tabular}

Source: Author's calculations based on WIIW (2010). 
Table 3. Regression results: common BITs coefficient (Model A)

\begin{tabular}{|c|c|c|c|}
\hline & $\begin{array}{c}(1) \\
\text { Dynamic FE }\end{array}$ & $\begin{array}{c}\text { (2) } \\
\text { Dynamic FE, } \\
\text { country trend }\end{array}$ & $\begin{array}{c}\text { (3) } \\
\text { GMM, BIT } \\
\text { endogenous }\end{array}$ \\
\hline L.FDI stock, Ln & $\begin{array}{l}0.672^{* * * *} \\
(0.0429)\end{array}$ & $\begin{array}{l}0.623^{* * * *} \\
(0.0417)\end{array}$ & $\begin{array}{l}0.832^{* * * *} \\
(0.0768)\end{array}$ \\
\hline L.BITs & $\begin{array}{c}0.00931 \\
(0.00565)\end{array}$ & $\begin{array}{l}0.0207^{*} \\
(0.0112)\end{array}$ & $\begin{array}{c}0.0162 \\
(0.0133)\end{array}$ \\
\hline L.Monthly wage, Ln & $\begin{array}{l}0.433^{* * *} \\
(0.161)\end{array}$ & $\begin{array}{c}0.221 \\
(0.186)\end{array}$ & $\begin{array}{l}0.433^{* * * *} \\
(0.150)\end{array}$ \\
\hline L.Inflation (\%), Ln & $\begin{array}{c}0.0277 \\
(0.0186)\end{array}$ & $\begin{array}{l}-0.0104 \\
(0.0199)\end{array}$ & $\begin{array}{c}0.0301 \\
(0.0190)\end{array}$ \\
\hline L.Political Constraints & $\begin{array}{c}0.207 \\
(0.145)\end{array}$ & $\begin{array}{l}0.0573 \\
(0.159)\end{array}$ & $\begin{array}{c}0.147 \\
(0.175)\end{array}$ \\
\hline L.Trade (\%GDP), Ln & $\begin{array}{l}0.417^{* *} \\
(0.195)\end{array}$ & $\begin{array}{l}0.447^{*} \\
(0.258)\end{array}$ & $\begin{array}{l}0.376^{* *} \\
(0.172)\end{array}$ \\
\hline Observations & 853 & 853 & 765 \\
\hline $\begin{array}{l}\text { Country-sector fixed } \\
\text { effects }\end{array}$ & $\mathrm{Y}$ & $\mathrm{Y}$ & $\mathrm{Y}$ \\
\hline Time dummies & Y & $\mathrm{Y}$ & Y \\
\hline Country-time trends & $\mathrm{N}$ & Y & $\mathrm{N}$ \\
\hline Number of instruments & & & 25 \\
\hline $\operatorname{AR}(2)(p$-value $)$ & & & 0.599 \\
\hline Sargan test ( $p$-value) & & & 0.239 \\
\hline Hansen test ( $p$-value) & & & 0.346 \\
\hline$R^{2}$ & 0.858 & 0.867 & 0.941 \\
\hline
\end{tabular}


Table 4. Regression results: separate BITs effect for each sector (Model B)

\begin{tabular}{|c|c|c|c|}
\hline & $\begin{array}{c}(1) \\
\text { Dynamic FE }\end{array}$ & $\begin{array}{c}(2) \\
\text { Dynamic FE, } \\
\text { country trend }\end{array}$ & $\begin{array}{c}\text { (3) } \\
\text { GMM, BIT } \\
\text { endogenous }\end{array}$ \\
\hline L.FDI stock, Ln & $\begin{array}{l}0.654^{* * * *} \\
(0.0423)\end{array}$ & $\begin{array}{l}0.590^{* * *} \\
(0.0431)\end{array}$ & $\begin{array}{l}0.778^{* * * *} \\
(0.0583)\end{array}$ \\
\hline BITs*Agriculture & $\begin{array}{c}0.00460 \\
(0.00650)\end{array}$ & $\begin{array}{c}0.0163 \\
(0.0134)\end{array}$ & $\begin{array}{l}0.0247^{*} \\
(0.0140)\end{array}$ \\
\hline BITs*Banking & $\begin{array}{c}0.00857 \\
(0.00542)\end{array}$ & $\begin{array}{l}0.0231^{* *} \\
(0.0103)\end{array}$ & $\begin{array}{l}0.0227^{*} \\
(0.0116)\end{array}$ \\
\hline BITs*Manufacturing & $\begin{array}{l}-0.000130 \\
(0.00497)\end{array}$ & $\begin{array}{c}0.0123 \\
(0.0110)\end{array}$ & $\begin{array}{c}0.0136 \\
(0.0121)\end{array}$ \\
\hline BITs*Mining & $\begin{array}{l}0.00612 \\
(0.0133)\end{array}$ & $\begin{array}{c}0.0174 \\
(0.0179)\end{array}$ & $\begin{array}{c}0.0190 \\
(0.0152)\end{array}$ \\
\hline BITs*Real Estate & $\begin{array}{c}0.0160^{*} \\
(0.00902)\end{array}$ & $\begin{array}{l}0.0335^{* * * *} \\
(0.0123)\end{array}$ & $\begin{array}{l}0.0300^{* * *} \\
(0.0120)\end{array}$ \\
\hline BITs*Services & $\begin{array}{l}0.000807 \\
(0.00548)\end{array}$ & $\begin{array}{c}0.0137 \\
(0.0111)\end{array}$ & $\begin{array}{c}0.0129 \\
(0.0117)\end{array}$ \\
\hline BITs*Utilities & $\begin{array}{l}0.0253^{* * * *} \\
(0.00737)\end{array}$ & $\begin{array}{l}0.0412^{* * * *} \\
(0.0111)\end{array}$ & $\begin{array}{l}0.0367^{* *} \\
(0.0186)\end{array}$ \\
\hline L.Monthly wage, Ln & $\begin{array}{l}0.401^{* * *} \\
(0.147)\end{array}$ & $\begin{array}{c}0.224 \\
(0.178)\end{array}$ & $\begin{array}{l}0.466^{* * * *} \\
(0.139)\end{array}$ \\
\hline L.Inflation (\%), Ln & $\begin{array}{c}0.0269 \\
(0.0186)\end{array}$ & $\begin{array}{l}-0.0179 \\
(0.0203)\end{array}$ & $\begin{array}{c}0.0220 \\
(0.0208)\end{array}$ \\
\hline L.Political Constraints & $\begin{array}{c}0.209 \\
(0.139)\end{array}$ & $\begin{array}{l}0.0716 \\
(0.153)\end{array}$ & $\begin{array}{c}0.201 \\
(0.151)\end{array}$ \\
\hline L.Trade (\%GDP), Ln & $\begin{array}{l}0.394^{* *} \\
(0.181)\end{array}$ & $\begin{array}{l}0.463^{*} \\
(0.254)\end{array}$ & $\begin{array}{l}0.388^{* *} \\
(0.165)\end{array}$ \\
\hline Observations & 853 & 853 & 765 \\
\hline $\begin{array}{l}\text { Country-sector fixed } \\
\text { effects }\end{array}$ & $\mathrm{Y}$ & $\mathrm{Y}$ & $\mathrm{Y}$ \\
\hline Time dummies & Y & Y & Y \\
\hline Country-time trends & $\mathrm{N}$ & Y & $\mathrm{N}$ \\
\hline Number of instruments & & & 43 \\
\hline $\operatorname{AR}(2)(p$-value $)$ & & & 0.677 \\
\hline Sargan test ( $p$-value) & & & 0.709 \\
\hline Hansen test ( $p$-value) & & & 0.220 \\
\hline$R^{2}$ & 0.862 & 0.872 & 0.890 \\
\hline
\end{tabular}


Table 5. Regression results: BITs variable interacted with the degree of sunkness using capital-per-firm proxy (Model C).

\begin{tabular}{|c|c|c|c|}
\hline & $\begin{array}{c}(1) \\
\text { Dynamic FE }\end{array}$ & $\begin{array}{l}\text { (2) } \\
\text { Dynamic FE, } \\
\text { country trend }\end{array}$ & $\begin{array}{c}(3) \\
\text { GMM }\end{array}$ \\
\hline L.FDI stock, Ln & $\begin{array}{l}0.663^{* * *} \\
(0.0395)\end{array}$ & $\begin{array}{l}0.607^{* * * 3} \\
(0.0391)\end{array}$ & $\begin{array}{l}0.744^{\text {***** }} \\
(0.0722)\end{array}$ \\
\hline L.BITs & $\begin{array}{l}0.00920^{*} \\
(0.00471)\end{array}$ & $\begin{array}{l}0.0228^{* * *} \\
(0.0104)\end{array}$ & $\begin{array}{c}0.0180 \\
(0.0127)\end{array}$ \\
\hline L.BITs*Sunkness & $\begin{array}{c}0.723^{* * *} \\
(0.235)\end{array}$ & $\begin{array}{l}0.819^{* * *} \\
(0.209)\end{array}$ & $\begin{array}{l}0.764^{* *} \\
(0.376)\end{array}$ \\
\hline L.Monthly wage, Ln & $\begin{array}{l}0.404^{* * * *} \\
(0.147)\end{array}$ & $\begin{array}{c}0.202 \\
(0.177)\end{array}$ & $\begin{array}{c}0.443^{* * *} \\
(0.155)\end{array}$ \\
\hline L.Inflation (\%), Ln & $\begin{array}{c}0.0272 \\
(0.0186)\end{array}$ & $\begin{array}{l}-0.0162 \\
(0.0200)\end{array}$ & $\begin{array}{c}0.0239 \\
(0.0184)\end{array}$ \\
\hline L.Political Constraints & $\begin{array}{c}0.208 \\
(0.140)\end{array}$ & $\begin{array}{l}0.0703 \\
(0.156)\end{array}$ & $\begin{array}{c}0.204 \\
(0.174)\end{array}$ \\
\hline L.Trade (\%GDP), Ln & $\begin{array}{l}0.387^{* *} \\
(0.185)\end{array}$ & $\begin{array}{l}0.453^{*} \\
(0.255)\end{array}$ & $\begin{array}{l}0.377^{* *} \\
(0.176)\end{array}$ \\
\hline Observations & 853 & 853 & 765 \\
\hline $\begin{array}{l}\text { Country-sector fixed } \\
\text { effects }\end{array}$ & $\mathrm{Y}$ & $\mathrm{Y}$ & $\mathrm{Y}$ \\
\hline Time dummies & Y & Y & Y \\
\hline Country-time trends & $\mathrm{N}$ & Y & $\mathrm{N}$ \\
\hline Number of instruments & & & 26 \\
\hline $\operatorname{AR}(2)(p$-value $)$ & & & 0.696 \\
\hline Sargan test ( $p$-value) & & & 0.588 \\
\hline Hansen test ( $p$-value) & & & 0.264 \\
\hline$R^{2}$ & 0.861 & 0.871 & 0.888 \\
\hline
\end{tabular}

BITs refers to the number of ratified BITs. Sunkness is proxied by fixed capital stock per firm. Robust standard errors in parentheses. ${ }^{*} p<0.10,{ }^{* *} p<0.05,{ }^{* * *} p<0.01$ 
Table 6. Regression results: Robustness tests with alternative BIT variables (1-4) and manufacturing industries (5)

(1) (2)

Dynamic FE, country trends (signed BITs)
(3)

Dynamic FE

(4) country trends

(BITs ratified with top (Manufacturing 15 capital exporters) industries)

\begin{tabular}{|c|c|c|c|c|c|}
\hline L.FDI stock, Ln & $\begin{array}{l}0.610^{\text {***** }} \\
(0.0454)\end{array}$ & $\begin{array}{l}0.625^{\text {*** }} \\
(0.0408)\end{array}$ & 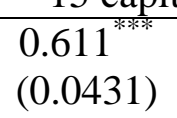 & $\begin{array}{l}0.622^{\text {***3 }} \\
(0.0412)\end{array}$ & $\begin{array}{l}0.593^{* \% *} \\
(0.0638)\end{array}$ \\
\hline BITs* Agriculture & $\begin{array}{c}-0.000339 \\
(0.0134)\end{array}$ & & $\begin{array}{c}0.0147 \\
(0.0368)\end{array}$ & & \\
\hline BITs* Banking & $\begin{array}{l}0.00463 \\
(0.0104)\end{array}$ & & $\begin{array}{c}0.0301 \\
(0.0243)\end{array}$ & & \\
\hline BITs* Manufacturing & $\begin{array}{l}-0.00707 \\
(0.0105)\end{array}$ & & $\begin{array}{l}0.00475 \\
(0.0249)\end{array}$ & & \\
\hline BITs* Mining & $\begin{array}{c}-0.000538 \\
(0.0178)\end{array}$ & & $\begin{array}{c}0.0380 \\
(0.0695)\end{array}$ & & \\
\hline BITs* Real Estate & $\begin{array}{c}0.0137 \\
(0.0118)\end{array}$ & & $\begin{array}{c}0.0478 \\
(0.0297)\end{array}$ & & \\
\hline BITs* Services & $\begin{array}{c}-0.00568 \\
(0.0107)\end{array}$ & & $\begin{array}{l}0.00695 \\
(0.0253)\end{array}$ & & \\
\hline BITs* Utilities & $\begin{array}{c}0.0131 \\
(0.0121)\end{array}$ & & $\begin{array}{c}0.0842^{* * * *} \\
(0.0253)\end{array}$ & & \\
\hline L.BITs ratified & & & & $\begin{array}{c}0.0308 \\
(0.0333)\end{array}$ & $\begin{array}{c}0.00518 \\
(0.00578)\end{array}$ \\
\hline $\begin{array}{l}\text { L.BITs ratified* } \\
\text { Sunkness }\end{array}$ & & & & $\begin{array}{l}2.963^{* * *} \\
(0.960)\end{array}$ & $\begin{array}{c}0.153 \\
(0.135)\end{array}$ \\
\hline L.BITs signed & & $\begin{array}{l}0.00313 \\
(0.0101)\end{array}$ & & & \\
\hline $\begin{array}{l}\text { L.BITs signed* } \\
\text { Sunkness }\end{array}$ & & $\begin{array}{l}0.582^{* *} \\
(0.246)\end{array}$ & & & \\
\hline L.Monthly wage, Ln & $\begin{array}{c}0.328^{*} \\
(0.183)\end{array}$ & $\begin{array}{l}0.312^{*} \\
(0.184)\end{array}$ & $\begin{array}{l}0.365^{* *} \\
(0.183)\end{array}$ & $\begin{array}{c}0.352^{*} \\
(0.192)\end{array}$ & $\begin{array}{c}0.313 \\
(0.193)\end{array}$ \\
\hline L.Inflation (\%), Ln & $\begin{array}{l}0.00141 \\
(0.0199)\end{array}$ & $\begin{array}{l}0.00231 \\
(0.0194)\end{array}$ & $\begin{array}{r}-0.00172 \\
(0.0198)\end{array}$ & $\begin{array}{l}0.00164 \\
(0.0193)\end{array}$ & $\begin{array}{l}0.00204 \\
(0.0157)\end{array}$ \\
\hline L.Political Constraints & $\begin{array}{c}-0.00789 \\
(0.153)\end{array}$ & $\begin{array}{c}-0.00973 \\
(0.155)\end{array}$ & $\begin{array}{c}0.00988 \\
(0.157)\end{array}$ & $\begin{array}{l}-0.0170 \\
(0.163)\end{array}$ & $\begin{array}{c}0.140 \\
(0.0898)\end{array}$ \\
\hline L.Trade (\% GDP), Ln & $\begin{array}{c}0.478^{*} \\
(0.257)\end{array}$ & $\begin{array}{c}0.468^{*} \\
(0.258)\end{array}$ & $\begin{array}{l}0.473^{*} \\
(0.260)\end{array}$ & $\begin{array}{c}0.441^{*} \\
(0.263)\end{array}$ & $\begin{array}{c}0.241^{*} \\
(0.135)\end{array}$ \\
\hline $\begin{array}{l}\text { Observations } \\
R^{2}\end{array}$ & $\begin{array}{c}853 \\
0.869 \\
\end{array}$ & $\begin{array}{c}853 \\
0.867\end{array}$ & $\begin{array}{c}853 \\
0.870\end{array}$ & $\begin{array}{c}853 \\
0.869 \\
\end{array}$ & $\begin{array}{l}1268 \\
0.831\end{array}$ \\
\hline
\end{tabular}

All specifications include country-sector fixed effects, time dummies and country-time trends. Sunkness is proxied by fixed capital stock per firm. BITs refers to the number of signed BITs in columns (1) and (2) and to the number of ratified BITs in columns (3), (4) and (5). Robust standard errors in parentheses. ${ }^{*} p<0.10,{ }^{* *} p<$ $0.05,{ }^{* * *} p<0.01$ 